(en particulier El Bekri Idrisi, Ibn Battouta, Al Omari, Ibn Khaldoun) mais il est fait utilisation aussi des premières sources portugaises et des tarikhs locaux. La tradition orale, codifiée dans des écrits modernes, donne une grande aide aussi. L'archéologie permet de compléter, surtout pour les pays du Sud, les lacunes des sources écrites et fournit des données précieuses dont ne parlent pas les textes. Après un exposé du cadre géographique, condition de la vie matérielle des populations envisagées, l'on passe aussitôt à l'étude de la vie économique, qui formera le centre de l'ouvrage. Passant à la géographie humaine, l'on essaie de reconstituer l'ethnographie ancienne du pays: l'organisation sociale, l'étude des religions - l'Islam et l'Animisme - sont ensuite abordées. Ce travail est destiné à faire le bilan de l'Ouest Africain depuis l'époque du rattachement du pays aux courants et influences extérieurs par les Arabes jusqu'à l'établissement des Portugais sur les côtes.

[Communicated by Raymond Mauny]

\title{
Programme des études de l'histoire de l'Afrique proposé par l'Ecole des Hautes Etudes, Paris
}

L'AFRICANISME français a accumulé un retard considérable dans le domaine historique. Ce retard est grave sur le plan scientifique où les sciences sociales et historiques se trouvent handicapées par la faiblesse de cette discipline de base; d'autre part, il prive les Africains d'une des assises essentielles de leur conscience culturelle. Cette situation n'exprime pas un manque d'intérêt pour le sujet, mais l'absence d'un cadre institutionnel dans lequel une telle discipline peut se développer.

La création d'un tel cadre semble possible en utilisant les possibilités de la Ve et de la VIe Sections de l'École Pratique des Hautes Études et M. Brunschwig, Professeur à l'École Nationale de la France d'Outre-Mer, accepterait de diriger sa mise en place.

En vue de la situation des études de l'histoire de l'Afrique, cette première année (1957-8) doit être considérée tout à fait comme préparatoire. Elle doit donner à $\mathrm{M}$. Brunschwig et à ses collaborateurs la possibilité d'étudier la situation à fond, de préparer un plan détaillé pour les années à venir, de prendre contact avec des chercheurs et des étudiants, et d'établir des instruments de travail.

Il sera donc prévu: un cours de M. Brunschwig sur l'histoire de l'Afrique, à la VIe Section; un voyage d'information de $M$. Brunschwig en Afrique pour prendre contact avec les érudits et les étudiants africains; la création de trois bourses pour les collaborateurs de M. Brunschwig et de l'aide financière aux chercheurs et érudits africains travaillant déjà dans ce domaine historique; la mise en marche des inventaires des archives concernant l'Afrique en France et dans l'Afrique Française et la préparation d'une bibliographie sur l'histoire précoloniale de l'Afrique; la formation de chercheurs dans le cadre du programme linguistique et africain de la VIe Section.

[Communicated by Clémens Heller]

\section{Programme de développement des sciences humaines en Côte d'Ivoire}

A partrr du is juillet 1957, une Section des sciences humaines, inaugurée par une décision du Ministère de l'Éducation de la Côte d'Ivoire, fonctionne à Abidjan sous le couvert du centre local de l'IFAN.

Dirigée par B. Holas, la nouvelle Section comprend le Département d'EthnologieSociologie et le Musée ethnographique (avec dépendances et le Groupe artisanal).

Un vaste programme, dont les premières réalisations matérielles sont prévues pour l'année 1958, comporte, d'un côté, un certain nombre d'enquêtes d'ordre ethnologique, 
sociologique, démographique et anthropologique (en collaboration avec des Services et organismes spécialisés) sur les populations locales, et de l'autre, un plan d'intensification des échanges des connaissances ainsi acquises avec des organismes de recherche en Afrique et ailleurs.

[Communicated by B. Holas]

\section{African Studies at the Centro de Estudos Politicos e Sociais, Lisbon}

The Portuguese Centro de Estudos Políticos e Sociais has recently undertaken a series of studies in Africa, concerned with cultural, economic, and governmental problems. In addition to its recent publications, it has sponsored studies of economic relations between Portugal and the Arab world and an inquiry into anti-colonialism which will be published before the end of 1957 .

In 1956 Professor Silva Cunha made a preliminary inquiry in Angola and Mozambique to plan a study of indigenous associations in Africa, an account of which has now been published. A field team, led by Professor Silva Cunha, assisted by José Maria Gaspar and André Gonçalves Pereira, will carry out investigations over three years from 1957. Professor Jorge Dias has made a field survey for an intensive study of ethnic minorities in the Portuguese African provinces by a field team in which he will be helped by Margot Schmidt Dias and Viegas Guerreiro over the four-year period I957-60. Fr. Ernesto Domingues, S.J. has made a preliminary study of migration in all Portuguese overseas territories on the basis of which a field team, led by Professor José Sampayo d'Orey, assisted by J. Castilho Soares and António Labisa, will carry out investigations which will include all African provinces.

Further information concerning the plans and progress of African studies at the Centro de Estudos Políticos e Sociais may be obtained from its Director, Dr. Adriano Moreira.

\section{Major Laing's Journey to Timbuktu, I825-6}

An article by Miss Maboth Moseley in West Africa (24 August 1957), called 'The Gap in the Shelf', throws new light on the journey made by Major Alexander Gordon Laing to Timbuktu in 1825-6, on the fate of his lost papers, and on the intrigues of Joseph-Louis Rousseau, French Consul-General in Tripoli at the time. Miss Moseley's article and her recently finished book of the same title are based on original documents, many of them unpublished, in the Public Record Office and the Archives of the Royal Society in London and on information from French sources, notably that supplied by Professor Th. Monod, Director of IFAN, Dakar.

\section{Social Study of the Anchau Resettlement Scheme, Northern Nigeria}

Professor H. Miner of the University of Michigan, with the aid of a Rockefeller Foundation grant, is engaged on a nine-month field study of the methods used and results achieved in the Anchau Resettlement Scheme, which was started twenty years ago in Northern Nigeria.

\section{Anthropological Research at the Institute of Social and Economic Research, Rhodes University, South Africa}

ANTHRopological research at the Institute of Social and Economic Research, Rhodes University, is at present mostly co-ordinated into three schemes, under the direction of Professor P. Mayer, for which the field is provided by the Xhosa-speaking peoples of the 